\title{
PHYSICAL ACTIVITY OF FEMALE STUDENTS OF THE UNIVERSITY SCHOOL OF PHYSICAL EDUCATION IN POZNAŃ ON THE BASIS OF IPAQ - EDUCATIONAL AND SOCIAL PERSPECTIVES
}

\author{
Marek Sokołowski ${ }^{1}$, Alicja Kaiser ${ }^{2}$, Algirdas Čepulėnas ${ }^{3}$ \\ Eugeniusz Piasecki University School of Physical Education in Poznañ ${ }^{1}$, Poland \\ Wielkopolska Higher School of Tourism and Management in Poznań2, Poland \\ Lithuanian Academy of Physical Education ${ }^{3}$, Kaunas, Lithuania
}

\begin{abstract}
Marek Sokołowski. Doctor of Physical Education Sciences. Assistant professor at the Department of Methodology of Physical Education in the Eugeniusz Piasecki University School of Physical Education in Poznań. Research interests: physical activity of people at various age, methodology of physical education and sport.
\end{abstract}

\begin{abstract}
In accordance with WHO's motto: "my health in my hands", contemporary approach to health issues concentrates on promoting active lifestyle of an individual. An individual's lifestyle determines one's health in 50-60\%, (which makes it the most significant factor). Other determinants of an individual's health-according to Marc Lalonde's health field concept-are: environment (21\%), biomedical (16\%), and healthcare services (10\%). Physical activity is an essential element of healthy lifestyle. Polish society is characterized by a low level of physical activity. Therefore, it is necessary to take social and educational actions in order to shape attitudes, habits or skills within this range. Currently, particular expectations are directed towards physical education teachers, who are propagating health education in Polish schools. It is essential to instruct teachers, who should not only possess didactic skills, but also (or even primarily) - they should set an example by their own behaviour. Resulting from the above mentioned issue, the aim of this work was to characterize physical activity of female students at the University School of Physical Education in Poznań from the perspective of pro-health influence they might have as future PE teachers. The characteristics of the respondents are presented with reference to their place of residence and type of sports discipline they train.

The research was based on the International Physical Activity Questionnaire (IPAQ). IPAQ is currently considered to be one of the best questionnaires used to analyse physical activity of people aged 15-69 years. For the analysis presented in this paper the shorter version of the questionnaire was used. It included seven questions concerning all types of physical activity (related to everyday life, work and leisure time). IPAQ is a method which makes use of metabolic equivalent - 1 MET.

The research was carried on among female students of the full-time programme, specialization: physical education teacher. The calendar age of the students was 19.8 years. The results based on the analysis revealed that the examined students represented high and sufficient level of physical activity. Students training individual sports, as well as those living in cities with more than 100000 inhabitants, reached higher values of MET coefficient than other respondents.
\end{abstract}

Keywords: lifestyle, health behaviour, physical activity, IPAQ.

\section{INTRODUCTION}

$\mathrm{T}$ The individual and social behaviour is intertwined in the aetiology of main health problems of the contemporary world. An individual's health depends on one's pro-health behaviour in $50 \%$. Lifestyle seems to be the dominating issue in achieving long-term health aims. Lifestyle is a combination of behaviours, actions, habits, customs; these might influence their relationship with health and the risk level of premature illness development. An individual's lifestyle is based on the relationship between living conditions and the individual behavioural patterns determined by the social and cultural factors as well as by the individual features. Lifestyle is 
a result of possibilities, conditions and choices. A significant component of healthy lifestyle is "physical activity". Physical activity is a term used interchangeably with "locomotive activity". However, in the worldwide information system it is encoded as "physical activity". It constitutes every work done by the skeletal muscles, which characterises itself by being over resting energy expenditure (Bouchard, Shephard, 1994).

Physical activity is an integral part of a complex process of adaptation in the history of human evolution (Malina, 1988); it is a fundamental and integral component of a healthy lifestyle. The significance of physical activity for health condition of a contemporary person is never to be overestimated (Baranowski et al., 1992; Jakicic et al., 2001; Jegier, 2006). Without it, any kind of health strategy is impossible; as well as its sustenance and multiplication. Furthermore, it is crucial at every stage of ontogenesis (Evans, Cyr-Campbell, 1997; Kwilecka, Brożek, 2007). Polish society is characterized by a low level of physical activity. Hitherto prevailing system of physical education in Poland scarcely prepares students to pay attention to their bodies, fitness and organism efficiency in further life. Currently, particular expectations are directed towards physical education teachers, who are propagating health education in Polish schools ${ }^{1}$. Modern educational influence of teachers is important, for they should not only possess didactic skills, but also (or even primarily) they should set an example by their behaviour.

Resulting from the above mentioned issue, the aim of this work is to characterize physical activity of female students at the University School of Physical Education in Poznan from the perspective of pro-health influence they might have as future training staff. Detailed aims of the research were as follows: a) to classify female students of the University School of Physical Education in Poznań in accordance with physical activity levels as described in the International Physical Activity Questionnaire (IPAQ); b) to evaluate the influence that the place of residence may have on the level of physical activity of female students of the University School of Physical Education in Poznań; c) to analyse the role that sports discipline trained by the examined students may have played in their physical activity behaviours.

Since 2009 educational standards concerning physical education in Poland include a wide range of pro-health actions, which shape pupils' attitude towards the needs of their bodies and health (http://www.reformaprogramowa.men.gov.pl/akty-prawne).

\section{METHODS}

Study materials. In order to achieve the goals of the study, a questionnaire was completed by 100 randomly chosen female students at Eugeniusz Piasecki University School of Physical Education in Poznan, who were at the full-time programme at the faculty of Physical Education with major: Physical Education. This specialization prepares for teaching at all levels of school education. The calendar age of the students was 19.8 years. All respondents consented voluntarily to participate in the study.

Research method. The level of physical activity in a population is usually evaluated with use of a questionnaire. The studies hitherto carried out in Poland used a variety of research tools, which made a comparative analysis difficult. Therefore, it is necessary to unify this procedure and use standardised research tools in order to obtain comparable empirical data within one country, but also to be able to compare them with those from other countries.

In the analysis discussed in the paper the International Physical Activity Questionnaire (IPAQ) (short version) was used. This was a pilot study, as it constituted a part of diagnoses and analyses presently introduced in Poland, making use of this research tool.

A team of scientists collaborated in Geneva, from 1998 until 1999, in order to create eight versions of IPAQ (four long versions and four short ones). Both, the long and the short versions, have two essential variations: "usual week" and "last 7 days". The questionnaire has been intended for people between the ages of $15-69$ years (Biernat et al. 2005, 2008; http://www.ipaq.ki.se/ipaq.htm). In 2004 Stupnicki and Biernat developed Polish versions of long and short IPAQ. There has also been developed an IPAQ version in Lithuanian (http://www.ipaq.ki.se/downloads.htm).

The questionnaire encompasses seven questions pertaining to all kinds of physical activity connected with everyday life, work and leisure time. The considered factors were the following: job-related activities; housework and house maintenance; physical activity spent on transportation from one place to another and also during leisure time devoted to recreation, exercise and other sports. Information concerning the time spent while sitting, walking, and time devoted to locomotive activity (either vigorous or moderate) was gathered. Only activities lasting at least 10 minutes (without a pause) were taken into consideration. 
In concord with IPAQ rules, the types of activities which lasted less than 10 minutes or longer than 10 minutes, but with pauses, were not considered. Possible exceptions to the rule were stopping at the red light during a walk or swapping the shopping from one hand to the other. In the case of walking one needs to make sure that the walk actually lasted 10 minutes without stopping and was not the so-called "being on feet". The term "being on feet" is characteristic for certain occupations such as teachers, nurses, etc. Physical activity has undoubtedly seasonal character, dependent on the climate, as well as with cultural factors such as: vacation, summer and winter break, holidays. It is recommended to conduct the research in November and March. In both those months the conditions for outdoors recreation are similar.

Every type of activity can be expressed in MET-min / week units. One needs to multiply the coefficient assigned to the activity by the number of days in a week it is performed in as well as by the number of minutes per day. The following is MET quota for different physical activities - short version: vigorous activity -8.0 ; moderate activity -4.0 ; walking -3.3 .

MET is computed according to the formula: minutes of vigorous activities per week $\times 8+$ minutes of moderate activities per week $\times 4+$ minutes of walking per week $\times 3.3$.

Example: Person " $\mathrm{X}$ " devotes per week: 180 min for vigorous activity; 240 min for moderate activity; $420 \mathrm{~min}$ for walking: MET $=180 \times 8+$ $240 \times 4+420 \times 3.3=3786$.

On the basis of the acquired results the subjects can be classified according to the level of their physical activity. three levels are distinguished:

1. High - the persons, who meet one of the following criteria: 3 or more days of vigorous physical activities, sum total of no less than 1500 MET; 7 or more days of whichever physical activity (walking, moderate or vigorous activity) exceeding 3000 MET.

2. Sufficient - the persons, who meet one of the three of the following criteria: 3 or more days of vigorous physical activities; lasting no less than 20 minutes a day; 5 or more days of moderate physical activities or walking, lasting no less that 30 minutes a day; 5 or more days of whichever physical activity (walking, moderate or vigorous activity) exceeding 600 MET.

3. Insufficient - the persons, who did not perform any kind of physical activity or did not meet the requirements for the sufficient or high level.
The division and criteria of classification to one of the levels include contemporary health directives stating that regularity is the basis of physical activity.

For the purpose this work, three additional questions were added to the questionnaire. They concerned detailed aims of the work.

\section{RESULTS}

The first stage of the data analysis involved calculating the value of MET coefficient for all the students. The results are given in Table 1.

While analysing weekly physical activity conveyed in MET units, it turned out that the majority of the examined students reached a very high result. The biggest group of the respondents (33\%) reached the level of $6001-8000$ MET. Only $11 \%$ had the results lower than 4000 MET.

Then, the analysis of students' physical activity with reference to their place of residence was carried out. The results are presented in Table 2 .

The results showed that among the students living in the cities with over 100000 inhabitants the biggest group (24\%) reached from 6001 to 8000 MET. It is worth emphasizing that as much as $22 \%$ of students from big cities were classified in the highest range of 10001-12000 MET. Among the students from the cities with less than 100 000 inhabitants, the most distinguishable (44\%) was the group of those who reached $6001-8000$ MET. The smallest group from this environment (4\%) included those who reached the results lower than 2000 MET. Among the students coming from the countryside, the biggest group (31\%) reached 8001-10000 MET. At the same time, the countryside inhabitants constituted the biggest group (15\%) with the results below 2000 MET.

In the next stage of the analysis, the independent variable was the type of sport discipline trained by the students. The results are presented in Table 3.

These results point to certain diversification in the compared groups, particularly between students who did not train professional sports and their colleagues who trained individual sports. Weekly physical activity portrayed in MET units among the studied female students who did not train sport professionally reached the score of 6001 to 8000 for the largest group (36\%). As many as $27 \%$ gained less than 2000 points and not a single one scored higher than 10000. Among the studied female students who trained team sports 


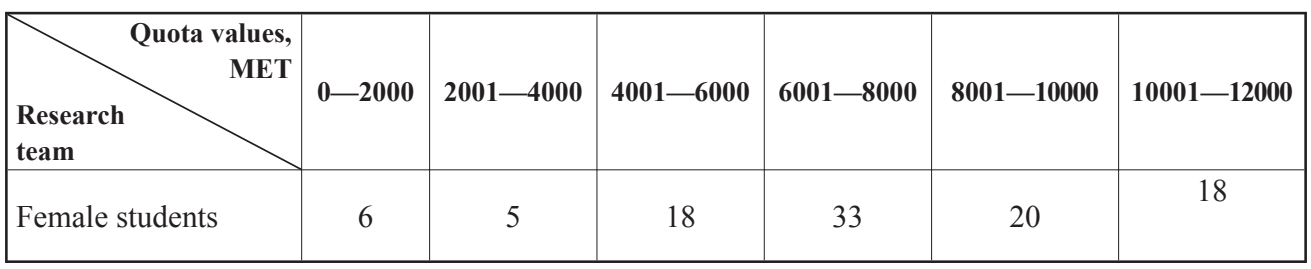

\begin{tabular}{|l|c|c|c|c|c|c|}
\hline $\begin{array}{r}\text { Quota values, } \\
\text { MET }\end{array}$ & $\mathbf{0 - 2 0 0 0}$ & $\mathbf{2 0 0 1 - 4 0 0 0}$ & $\mathbf{4 0 0 1 - 6 0 0 0}$ & $\mathbf{6 0 0 1 - 8 0 0 0}$ & $\mathbf{8 0 0 1 - \mathbf { 1 0 0 0 0 }}$ & $\mathbf{1 0 0 0 1 - 2 0 0 0}$ \\
$\begin{array}{l}\text { Place of } \\
\text { residence }\end{array}$ & 5 & 5 & 22 & 24 & 22 & 22 \\
\hline $\begin{array}{l}\text { Cities with more than } \\
100 \text { 000 inhabitants }\end{array}$ & 4 & 6 & 14 & 44 & 16 & 16 \\
\hline $\begin{array}{l}\text { Cities with less than } \\
100 \text { 000 inhabitants }\end{array}$ & 15 & 0 & 23 & 15 & 31 & 15 \\
\hline Countryside & & & & & & 16 \\
\hline
\end{tabular}

\begin{tabular}{|l|c|c|c|c|c|c|}
\hline $\begin{array}{r}\text { Quota values, } \\
\text { MET } \\
\text { of practiced sport }\end{array}$ & $\mathbf{0 - 2 0 0 0}$ & $\mathbf{2 0 0 1 - 4 0 0 0}$ & $\mathbf{4 0 0 1 - 6 0 0 0}$ & $\mathbf{6 0 0 1 - 8 0 0 0}$ & $\mathbf{8 0 0 1 - 1 0 0 0 0}$ & $\mathbf{1 0 0 0 1 - 1 2 0 0 0}$ \\
\hline $\begin{array}{l}\text { I do not train } \\
\text { professionally }\end{array}$ & 27 & 0 & 14 & 36 & 23 & 0 \\
\hline $\begin{array}{l}\text { I train team sports } \\
\text { I train individual } \\
\text { sports }\end{array}$ & 0 & 7 & 20 & 28 & 25 & 0 \\
\hline
\end{tabular}

\begin{tabular}{|l|c|c|c|}
\hline $\begin{array}{r}\text { Levels of female } \\
\text { students' activities }\end{array}$ & High & Sufficient \\
Team
\end{tabular}

\begin{tabular}{|l|c|c|c|}
\hline $\begin{array}{r}\text { Levels of female students' } \\
\text { physical activity }\end{array}$ & High & Sufficient & Insufficient \\
\hline $\begin{array}{l}\text { Place of residence } \\
\text { inhabitants more than } 100000\end{array}$ & 89 & 11 & 0 \\
\hline $\begin{array}{l}\text { City with less than } 100000 \\
\text { inhabitants }\end{array}$ & 94 & 6 & 0 \\
\hline Countryside & 85 & 15 & 0 \\
\hline
\end{tabular}

\begin{tabular}{|c|c|c|c|}
\hline $\begin{array}{l}\text { The type } \\
\text { of practised sport }\end{array}$ & High & Sufficient & Insufficient \\
\hline I do not train professionally & 73 & 27 & 0 \\
\hline I train team sport & 92 & 8 & 0 \\
\hline I train individual sport & 100 & 0 & 0 \\
\hline
\end{tabular}

the largest group (28\%) ranged from 6001 to 8000 , and as many as $20 \%$ from 10001 to 12000 , and not a single one scored less than 2000 . The largest part of the studied female students who trained individual sports $(38 \%)$ also reached the values
Table 1. Physical activity of the examined students conveyed in MET units $(n=100)$ (percentage analysis)

Table. 2. MET according to place of residence $(n=$ 100) (percentage analysis)

Table 3. MET according to the professionally practised sport $(n=100)$ (percentage analysis)

Table 4. Levels of physical activity in the IPAQ reached by the female students $(\mathrm{n}=100)$ (percentage analysis)

Table 5. The level of physical activity in the IPAQ achieved by the female students depending on the place of residence $(n=100)$ (percentage analysis)

Table 6. The level of physical activity in the IPAQ reached by the female students depending on the type sport trained professionally $(n=100)$ (percentage analysis) ranging between 6001 to 8000 ; whereas only $5 \%$ of them received 2001 to 4000 points and none of them dropped below 2000. It should be underlined, that $25 \%$ of them reached a very high result of 10001-12000 MET. 
In the further analysis the students were classified in accordance with IPAQ three levels of physical activity (Table 4).

On the basis of the International Physical Activity Questionnaire as much as $91 \%$ of the examined students reached high level, while only $9 \%$ - sufficient. None of the students reached insufficient level.

Taking into consideration place of residence the results were the following (Table 5).

We see that from among the students living in the cities with over 100000 inhabitants $89 \%$ reached high level, and $11 \%$ - sufficient. Students from the cities with less than 100000 inhabitants produced better results: $94 \%$ reached high level, and only $6 \%$ - sufficient. The worst results were achieved by the students from the countryside: $85 \%$ - high level, $15 \%$ - sufficient.

Considering sports discipline in the light of the International Physical Activity Questionnaire, it turned out that $73 \%$ of the respondents who did not train sport professionally reached high level, while $27 \%$ - sufficient level of physical activity. Among students training team sports as much as $92 \%$ reached high level, $8 \%$ - sufficient. However, the best results were reached by students training individual sports - they all reached high level (Table 6).

\section{DISCUSSION}

In spite of some symptoms of improvement, health condition of the Polish society is alarming. Diseases that affect us most often have their source in incorrect health-related behaviours. Low physical activity of the population is of particular significance here. In Poland too many people live below biological locomotive level which is necessary for better health and proper functioning of their organisms. It is estimated that about $30 \%$ of children and youth and $10 \%$ of adults do various forms of training the variety and intensity of which satisfy basic physiological needs of an organism (National Health Programme 2007-2015). Various research and polls reveal negative attitude towards physical effort among different age and social groups in the Polish society (Cabak, Woynarowska, 2004; Woynarowska, 2008). These studies collected data using of many different methods, measurement tools, varied research samples, which makes it impossible to compare them in detail. It is particularly difficult in the case of research applying the International Physical Acti- vity Questionnaire, since it has been in use for a short time.

However, analysing the results of our own research in comparison with other research in student environment, the results were highly optimistic. Generally, students represent low level of physical education (Fijewski, 1998; Bartkowiak, 2001; Lisicki, 2004; Suliga, 2004; Kowalewski, 2006; Marchewka 2010). High results obtained in the research may stem from the specific type of studies of the respondents, which is confirmed by other research among students of physical education (cf.: Królikowska, 2003; Duda, 2005; Sokołowski, 2008; Sieńko-Awierianów, Wesołowska, 2010). Similarly good results concerning the level of physical activity determined by IPAQ were achieved in military environment (Mierzejewski, 2008; Kaiser, Sokołowski, 2008; Sokołowski et al., 2009; Lenart, 2010). This is undoubtedly related with the fact, that people who want to meet the requirements of military service must be characterised by good fitness, shaped by daily physical activity.

The level of physical activity displayed by students of physical education creates a good basis for their future role in promoting physical education in their social environment (at work, in family, in local community). Only people who represent high level of physical consciousness can meet the new educational requirements in the domain of pro-health physical education. Thus, the results of the analysis are optimistic and promising. They give hope that physical activity of present-day students will be reflected in the future, and will become an inseparable element of PE teachers' lifestyle.

\section{CONCLUSIONS}

On the basis of the research results the following conclusions may be drawn:

The respondents from the University School of Physical Education display high and sufficient levels of physical activity, in accordance with the criteria of the International Physical Activity Questionnaire (IPAQ). None of the respondents was classified as insufficient in their level of physical activity.

Taking into consideration the place of residence of the respondents it turned out that that the best results were reached by students from cities with less than 100000 inhabitants, while the worst - by those from the countryside. 
Students training individual sports reached higher values of MET coefficient than students training team sports or those who did not train sports professionally.
The level of physical activity displayed by the examined students of physical education creates a good basis for their future role in promoting health through physical activity.

\section{REFERENCES}

Baranowski, T., Bouchard, C., Bar-Or, O. et al. (1992). Assessment, prevalence and cardiovascular benefis of physical activity and fitness in youth. Medicine and Science in Sports and Exercise, 24, S 237-247.

Bartkowiak, L. (2001). Zdrowy styl życia w poglądach studentów wydziału farmaceutycznego. Problemy Medycyny Społecznej, 34, 56-62.

Biernat, E., Stupnicki, R. (2005). An overview of internationally applicable questionnaires designed for assessing physical activity. Physical Education and Sport, 49, 32-42 (Internet link: www.pheds.com).

Biernat, E., Stupnicki, R., Lebiedziński, B., Janczewska, L. (2008). Assessment of physical activity by applying IPAQ questionnaire. Physical Education and Sport, 52, $83-89$.

Bouchard, C., Shephard, R. J. (1994). Physical activity, fitness and health: the model and key concepts. In Physical Activity, Fitness and Health. International Proceedings Consensus Statement (pp.11-22). Champaign: Human Kinetics Publishers.

Cabak, A., Woynarowska, B. (2004). Physical activity of youth aged $11-15$ years in year 2002 in Poland and other countries, Physical Education and Sport, 4, 361-365.

Duda, B. (2005). Aktywność fizyczna studentów Akademii Wychowania Fizycznego i Sportu w Gdańsku przykładem zdrowego stylu życia. Annales UMCS Sectio D, 157, $291-296$.

Evans, W. J., Cyr-Campbell, D. (1997). Nutrition, exercise, and healthy aging. Journal of the American Dietetic Association, 6, 632-638.

Fijewski, A. (1998). Postawy studentów medycyny wobec kultury fizycznej i zdrowotnej, Kultura Fizyczna, 1-2, $21-24$.

Jakicic, J. M., Clark, K., Coleman, E. et al. (2001). American College of Sports Medicine position stand. Appropriate intervention strategies for weight loss and prevention of weight regain for adults. Medicine Science in Sports Exercise, 33, 2145-2156.

Jegier, A. (2006). Aktywność ruchowa w promocji zdrowia oraz zapobieganiu chorobom przewlekłym. In A. Jegier, K. Nazar, A. Dziak (Eds.), Medycyna Sportowa (pp. 403-456). Warszawa: PTMS.

Kaiser, A., Sokołowski, M. (2009). Health and social issues of women in the army. In M. Sokołowski (Ed.). Contemporary Tasks, Problems and Perspectives of Physical Education in the Army (pp. 313-322). Warszawa: Polish Scientific Physical Education Association Section of Physical Education in the Army.

Kowalewski, I. (2006). Kultura zdrowotna studentów. Diagnoza i perspektywy. Kraków: Wydawnictwo Naukowe Akademii Pedagogicznej.

Królikowska, B. (2003). Styl życia studentów wydziału wychowania fizycznego i fizjoterapii politechniki opolskiej. Annales UMCS Section D, 134, 158-162.
Kwilecka, M., Brożek, Z. (2007). Bezpośrednie funkcje rekreacji. Warszawa: Almamer.

Lenart, D. (2010). Aktywność fizyczna a rozwój morfofunkcjonalny kobiet. In J. Łuczak, S. Bronowicki (Eds.), Zdrowotne aspekty aktywności fizycznej (pp. 245-253). Poznań: Wielkopolska Wyższa Szkoła Turystyki i Zarządzania w Poznaniu.

Lisicki, T. (2004). Aktywność ruchowa studentów. Potrzeby społeczne - stan-warunki realizacji. Gdańsk: AWFiS.

Malina, R. M. (1988). Physical activity in early and modern populations: An evolutionary view. In R. M. Malina, H. M. Eckert (Eds.), Physical Activity in Early and Modern Populations, American Academy of Physical Education Papers (No 21, pp. 1-12). Champaign, IL: Human Kinetics.

Marchewka, J. (2010). Aktywność fizyczna w stylu życia studentów Uniwersytetu Jagiellońskiego. In A. Kaiser, M. Sokołowski (Eds.), Środowisko społeczno-przyrodnicze a aktywność fizyczna człowieka (pp. 255-272). Poznań: Wielkopolska Wyższa Szkoła Turystyki i Zarządzania w Poznaniu.

Mierzejewski, R. (2008). Ocena poziomu aktywności fizycznej żołnierzy Wojsk Lądowych na podstawie Międzynarodowego Kwestionariusza Aktywności Fizycznej (IPAQ). In E. Szczepanowska, M. Sokołowski (Eds.), Aktywność fizyczna i odżywianie sie jako uwarunkowania promocji zdrowia (pp. 225-232). Poznań: Wielkopolska Wyższa Szkoła Turystyki i Zarządzania w Poznaniu.

Narodowy Program Zdrowia 2007-2015. Internet link http://www.mz.gov.pl.

Sieńko-Awierianów, E., Wesołowska J. (2010). Aktywność fizyczna studentów wychowania fizycznego. In A. Kaiser, M. Sokołowski (Eds.), Środowisko społeczno-przyrodnicze a aktywność fizyczna człowieka (pp. 231-237). Poznań: Wielkopolska Wyższa Szkoła Turystyki i Zarządzania w Poznaniu.

Sokołowski, M. (2008). Międzynarodowy kwestionariusz aktywności fizycznej (IPAQ) jako miernik oceny aktywności fizycznej studentów Akademii Wychowania Fizycznego. In E. Szczepanowska, M. Sokołowski (Eds.), Aktywność fizyczna $i$ odżywianie sie jako uwarunkowania promocji zdrowia (pp.113-124). Poznań: Wielkopolska Wyższa Szkoła Turystyki i Zarządzania w Poznaniu.

Sokołowski, M., Mrozkowiak, M., Kaiser, A. (2009). International physical activity questionnaire (IPAQ) as a tool to assess the potential regular soldiers. In E. Szczepanowska, M. Sokołowski (Eds.), Aktywność fizyczna $i$ odżywianie sie jako uwarunkowania promocji zdrowia (pp. 349-355). Poznań: Wielkopolska Wyższa Szkoła Turystyki i Zarządzania w Poznaniu.

Suliga, E. (2004). Zachowania zdrowotne studentów kieleckich i uczniów szkót ponadgimnazjalnych z południowej i środkowo-wschodniej Polski. Kielce: Wydawnictwo Akademii Świętokrzyskiej.

Woynarowska, B. (2008). Edukacja zdrowotna. Warszawa: PWN. 


\title{
POZNANĖS KŪNO KULTŪROS AKADEMIJOS STUDENČIŲ FIZINIS AKTYVUMAS REMIANTIS TARPTAUTINIO FIZINIO AKTYVUMO KLAUSIMYNO (IPAQ) DUOMENIMIS: UGDYMO IR SOCIALINĖS PERSPEKTYVOS
}

\author{
Marek Sokołowski $^{1}$, Alicja Kaiser ${ }^{2}$, Algirdas Ćepulenas ${ }^{3}$ \\ Poznanès Eugenijaus Piaseckio kūno kultūros akademijal', Poznanè, Lenkija \\ Wielkopolska aukštoji turizmo ir vadybos mokykla ${ }^{2}$, Poznanè, Lenkija, \\ Lietuvos kūno kultūros akademija ${ }^{3}$, Kaunas, Lietuva
}

\begin{abstract}
SANTRAUKA
Anot pasaulinès sveikatos organizacijos moto (,Mano sveikata mano rankose“), šiuolaikiškas sveikatos principas yra garantuoti aktyvų žmogaus gyvenimo būdą. Sveiką gyvenseną siekiama palaikyti, stiprinti ir sugrąžinti sveikatą. Gyvenimo būdas $50-60 \%$ lemia asmens sveikatos būklę, dèl to jis yra svarbiausias sveikata palaikantis veiksnys. Kiti, kaip nurodo Marc Lalonde sveikatos koncepcija, yra aplinkos (21\%), biomedicininiai (16\%) ir sveikatos apsaugos paslaugu (10\%) veiksniai. Sveika gyvensena - tai sąmoninga žmogaus elgsena ir pasirinkimas norint išsaugoti sveikatą.

Šio tyrimo tikslas - iqvertinti Poznanès kūno kultūros akademijos studenčių fizini aktyvumą remiantis tarptautiniu fizinio aktyvumo klausimynu IPAQ (International Physical Activity Questionare). Šiuo metu jis yra pripažintas vienu iš geriausių klausimynų, ivvertinančiu 15-69 metų žmonių fizini aktyvumą. Tyrimo metu naudojome trumpesnę šio klausimyno versiją. Joje pateikiami septyni klausimai apie visų sričių (kasdienio gyvenimo, darbo ir laisvalaikio) fizini aktyvumą. Klausimynas apima asmens veiklą darbe, namie, rekreacijai skirtą laiką, fizinius pratimus, kartu ir laika, praleidžiamą sėdint, vaikščiojant ir mankštinantis. Vertindami fizinio aktyvumo lygmenis nagrinejome tik tą veikla, kuri be pertraukos truko ne mažiau kaip 10 minučių. IPAQ metodika naudoja metabolinį vienetą METĄ. Nepriklausomi tyrimo kintamieji — studenčių gyvenamoji vieta ir jų lankoma sporto šaka. Buvo tiriama 100 atsitiktinai parinktų studenčių iš Kūno kultūros fakulteto.

Apklausėme nuosekliujų studijų studentes, kurių amžiaus vidurkis 19,8 metai. Tarp jų 22\% profesionaliai nesportavo, $40 \%$ lankè komandinio sporto šakas, ir 38\% — individualias sporto šakas. Individualios sporto šakos populiariausios tarp studenčių iš miestų, turinčių per 100000 gyventojų, o komandinį sportą daugiausia rinkosi kaimo gyventojos.

Tyrimo rezultatai parodè, kad tiriamosios yra didelio ir pakankamo fizinio aktyvumo. Geriausių rezultatu šioje srityje pasiekè studentès iš didelių miestų, kurios lankẻ individualių sporto šakų pratybas. Palyginus šio akademinès aplinkos tyrimo rezultatus su kitais galima teigti, kad atlikto tyrimo rezultatai visos Lenkijos studentų populiacijos požiūriu yra ypač palankūs.
\end{abstract}

Raktažodžiai: gyvenimo būdas, sveika gyvensena, fizinis aktyvumas, tarptautinis fizinio aktyvumo klausimynas IPAQ. 